\title{
POLICY STRATEGY TO MANAGE SUSTAINABILITY OF SITU (SMALL LAKE) KEDAUNG IN PAMULANG DISTRICT, SOUTH TANGERANG, BANTEN-INDONESIA
}

\begin{abstract}
Agus Susanto
ABSTRACT

South Tangerang City Government set it Situ (small lake) Kedaung as one of the conservation program, because of 9 there were 4 of which have been lost or switching functions, and 3 endangered missing, one of them is Situ Kedaung. For it is necessary to study the level of sustainable conservation to utilization Situ Kedaung. This study aims to analyze the index and status sustainability of 5 (five) dimensions of sustainability, using the data step MultiDimensional Scaling (MDS), and the results are expressed in the form of index and status of sustainability. To determine the attributes that are sensitive and affect the index and status sustainability and influence of Laverage and Montecarlo analysis. As for the scenarios increase the sustainability of the future status is a prospective analysis. The analysis showed that the ecological dimensions of sustainability are at less status (37.32), the economic dimension is the less sustainable status (26.05), the social dimension is the less sustainable status (40.28), the dimensions of the technology is fair sustainable status (57.20), and institutional dimensions are less sustainable (26.91). The results of the analysis of all the dimensions of sustainability for situ Kedaung is included in the category or status less sustainable with index value of 36.65. Of the 37 attributes that were analyzed, there were 14 attributes that need to be addressed as it is sensitive affect. Based on a prospective analysis, there are 5 critical attributes that must be managed in order to maintain sustainability. These five attributes include: water pollution, ecotourism, conservation, community income, and local regulatory agencies, hereinafter referred to as key attributes. To improve the status of sustainability in the future (over the medium and long term), there are three scenarios : (1) Conservative-Pessimistic (survive the conditions that exist while holding make shift repairs), (2) moderate- Optimistic (make improvements but not optimal) and (3) Progressive- Optimistic (make comprehensive and integrated improvements).
\end{abstract}

Keywords: Index and status sustainabilit, sensitive attributes, scenarios increase the sustainability status 


\section{INTRODUCTION}

South Tangerang City hydrologically has nine (9) Situ. are: Situ Pamulang or Tujuh Muara, Kedaung/Sasak, Parigi, Rawa Kutuk, Gintung, Bungur, Legoso, Rumpang, and Kayu Antap (Dinas Bina Marga dan Sumber Daya Air Kota Tangsel, 2011). The existing condition of the nine Situ around four Situ were declared missing, due to various problems such as: changing the function of rice fields or residential, such as: Situ Legoso, Rumpang, Kayu Antap, Bungur. In addition, there are three Situ more vulnerable missing, because the condition due to bank erosion and silting of erosion upstream areas, pollution, and the broken down levee that need immediate attention are: Situ Pamulang, Parigi and Kedaung.

Situ Kedaung (Sasak) is one of the vurnability Situ, are formed naturally. Utilization is as a source of water for the irrigation of agricultural crops in the area downstream of the region of Kampung Sawah and Serua, as well as for fisheries activities. For local communities, fisheries activities serve as a source of livelihood, which is developed fisheries and aquaculture with floating nets for daily use (subsistence) .

The problem faced is: nearly $70 \%$ lakeside overgrown aquatic plants such as kangkung (Ipomea aquatic), enceng gondok (Eichhornia crasipes) in a large population, and at the edge of the lake found the existence of wood processing industry that utilizes the lake water as a source of raw water and waste disposal, in addition lakeside not common annual plants and plaster which serves as a barrier to erosion, so often happens cliff erosion will lead to siltation of the lake. Another issue is the higher urbanization, this results in the need for land for residential. This phenomenon will have an impact on land occupation around the larger Situ, thus diminishing vast Situ (shrinkage)

\section{NOMENCLATURE}

By considering these phenomena, will be reviewed status and index sustainability of Situ Kedaung is seen from 5 (five) dimensions of sustainable development, namely ecological, economic, sociocultural, technological, and institutional. It is expected from the results of this study that it can provide input to the policy of South Tangerang city government in the management of Situ in South Tangerang, because in this study generated scenario or strategy development (prospective development) situ, so has the research objectives : (a) identify attributes that influence the sustainability dimension, (b) Analyze the index and status of 
sustainability management situ views from the 5 dimensions of sustainable development (ecological, economic, social, cultural, technological, and institutional), and

(c) develop sustainable strategies for Situ Kedaung management policies.

\section{METHODOLOGY}

To assess the sustainability of Situ Kedaung quickly (rapid appraisal) used multiple methods of non - parametric attributes (multi dimentional scaling $=$ MDS), which is a modification of the RAP - fish (The Rapid Appraisal of the Status of Fishing). Data analysis was performed through several stages, namely: (1) the step of determining the attributes or criteria for the sustainable management of the Situ, includes five dimensions (ecological, economic, social, institutional, and technological), (2) the stage of assessment of each attribute in an ordinal scale based on the criteria of sustainability each dimension, (3) the analysis phase ordinated sustainability index value using MDS. Sustainability index values in this analysis are grouped into 4 categories status of sustainability, namely: 0-30 (bad), 31-50 (less), 51-75 (fair) and 76-100 (good). As for generating scenarios in a sustainable development of the Situ used Prospective Analysis is to determine the key factors that affect the performance of the system.
Influence between factors is given a score by an expert using a scoring guide prospective analysis. Scenarios that may occur in the future may be a conservative pessimistic, moderate - optimistic, and progressive - optimistic.

\section{RESULTS AND DISCUSSIONS}

\section{Location of Study}

Geographically located at coordinates Situ Kedaung is 06 $16^{0} 48$ " - 06 $21^{0} 50$ " SL, and $106^{\circ} 44^{\prime} 31$ " - 106 $45^{\prime} 40$ " EL, has an area of 20 hectares, with an average depth of 2 meters. While administratively located in the Bambu Apus West Pamulang village, Pamulang sub-district, and Cipayung and Ciputat village, Ciputat sub-district. a lowlying area, and relatively flat topography, average slope 0-3 \%, whereas altitude region ranged between 15-20 meters above sea level, which is formed by rock formations Alluvium (Qa) which consists of alluvial rivers and swamps, and in geomorphology included in the unit morphology coastal plain.

Annual rainfall average of $1,744 \mathrm{~mm}$. The highest falls in February of $664 \mathrm{~mm}$, and the smallest $1.0 \mathrm{~mm}$ that fell in July. The number of rainy days is 137 days, and the average within 1 year of 11.4 days, so climate type by Schmidt \& Fergusson belong to the type $\mathrm{B}$, type of climate that is characterized wet months as 6 months, and months dry as much as 4 months. Kedaung 
initially formed naturally. In the 1960 's was built and expanded their area. Originally extent has \pm 30.0 ha, with a depth of 7-8 meters. In the 1990s, vast lakes stay 25.32 ha, with a depth of 3-4 meters, and at the present time the extent of stay of 20.0 hectares, with a depth of stay 2-3 meters. The source of water comes from rain, groundwater is emerging as a spring bottom and around the Situ, and river Kedaung spring is at the foot of Mount Salak. Kedaung River have perennial flow, which means that the water is always flowing river throughout the year, with a parallel pattern. Fluctuations in lake water ranges between 12 meters.

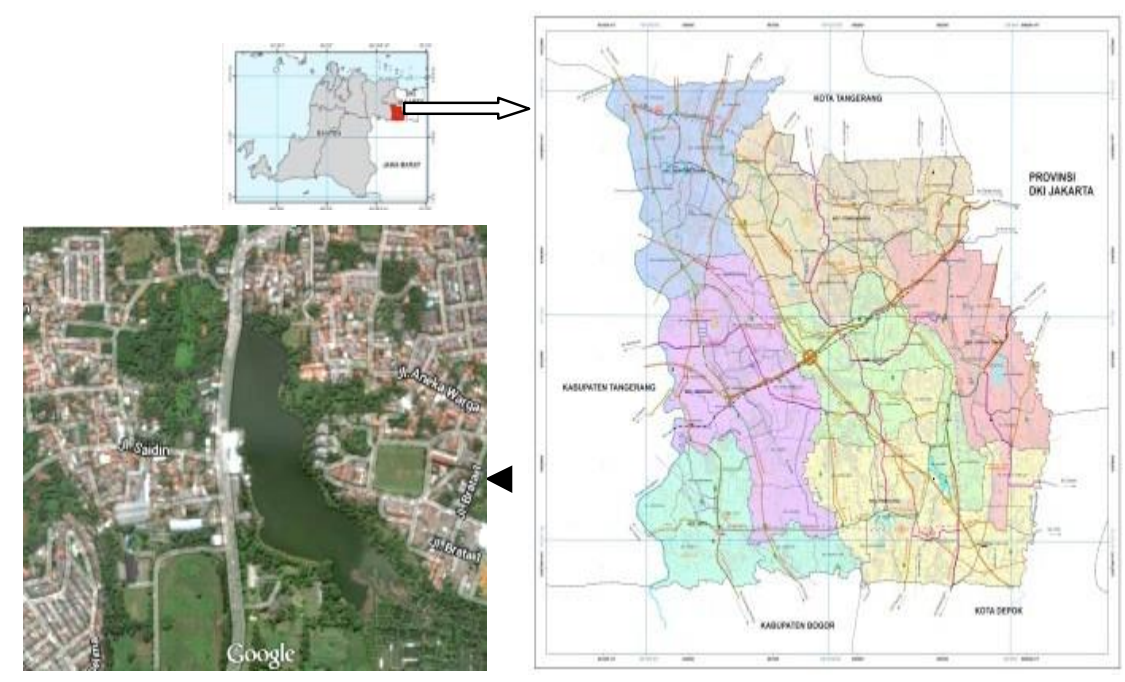

Figure 1. Map of location's research

The quality of water, the $\mathrm{pH}$ range between $5.8-6.3$, the temperature range between $30^{\circ} \mathrm{C}-33^{\circ} \mathrm{C}$. TSS in the inlet area is relatively high, then declined in the middle, and near the outlet. The same phenomenon occurs in turbidity. While the electrical conductivity (EC) of height in the upstream (inlet ), then lower in the body of the lake, and at the outlet rather high.

\section{Analysis}

The results of RAP - Fish multidimensional analysis using techniques ordinated through the MDS method generates an index value of sustainability management Situ Kedaung of 36.65 . Sustainability index value lessr sustainable category because its value is between 30 to 50. The value of sustainability index is obtained based on an assessment of the 37 attributes are included in the five dimensions of ecology (9 attributes), the economic dimension (9 attributes), the social dimension (9 attributes), the institutional dimension (6 attributes), and 
the dimensions of technology (4 attributes).

The results of the analysis of RAP - Fish besides sustainability index values were also obtained stress values and the value of R2. The analysis shows the stress value of 0.14 , meaning that is under 0.25 so the results of this analysis is quite good. The R2 (coefficient of determination) indicates the relationship between the system attributes are used. R2 values were obtained in the amount of 0.946 indicates that the system by using the attributes are now explained 94.60 $\%$ of the existing system. This value indicates that the attribute is used as an indicator of which were scored (weighted), is able to explain that behavior management Kedaung Lake of $94.60 \%$. Thus all the attributes of the five dimensions used are quite good in explaining conditions Situ Kedaung management system available of each dimension and sensitive attributes affect the sustainability management has conducted the analysis Siyu Kedaung RAP - Fish and analysis of leverage on each dimensions.

\section{Ecology Dimension}

The results of the analysis of the index utilization sustainability Situ Kedaung from ecological dimension is 37.32. It is in the the category of less sustainable because the value of the index is in the range of 30-50. And results of the Leverage analysis from nine atribut of ecological dimention showed there are three (3) sensitive attributes, namely the status of water pollution, the condition of eco-tourism, and conservation activities. These three attributes are closely related, because the pollution level attributes affect conservation and

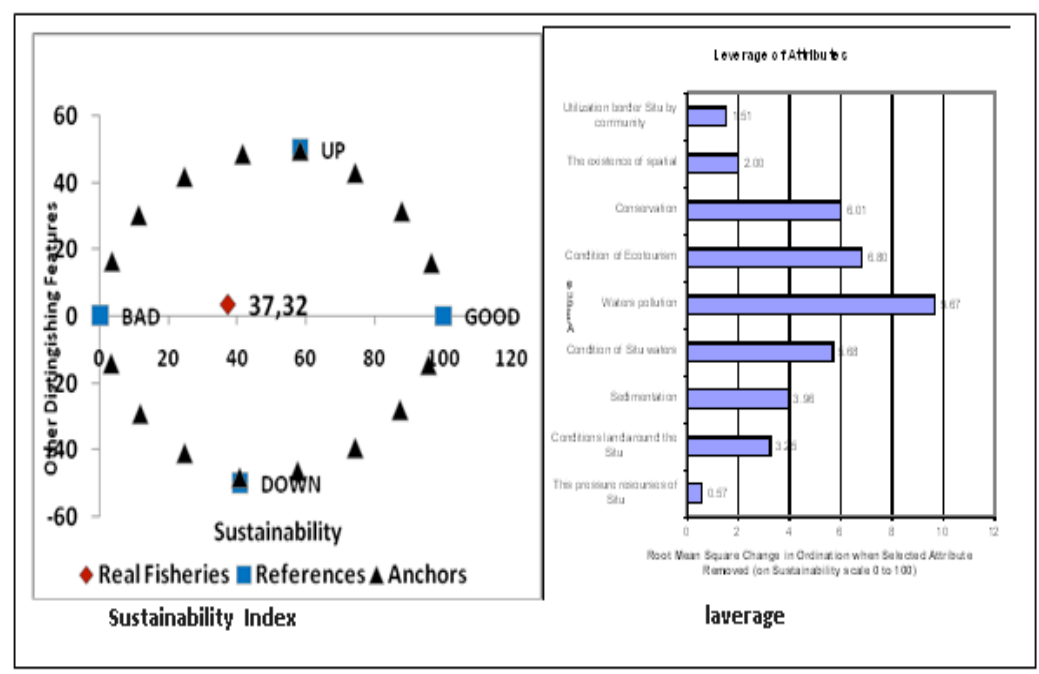

today. To determine the sustainability index

ecotourism activities.

Figure 2. Value of Index sustainable and each atribut from ecology dimentions

\section{Economic Dimension}


The results of the analysis of the index utilization sustainability Situ Kedaung of the economic dimension shows an index of 26.05 , including the bad category because that value of the index is at an interval of 0 30. Results of the Leverage analysis showed of economic sustainability of the nine attributes are analyzed, there are three (3) sensitive attributes affect management Situ Kedaung, namely: average income of the community against the minimum regional salary (UMR), institutional economics (a partnership), and the absorption of labor. Employment attribute a great effect on the average income of the people against the minimum wage, because these attributes include a broad influence directly the existence of Situ Kedaung includes four villages namely Pamulang Barat, and Bambu Apus included in Pamulang subdistrict, while two more villages, namely: Ciputat, and Cipayung village belongs to the Ciputat sub-district. Similarly with the partnership (economic institutions) had enormous influence on employment and income of the community, because economic institutions will have an impact on the performance of the labor that will certainly have an impact on people's incomes.

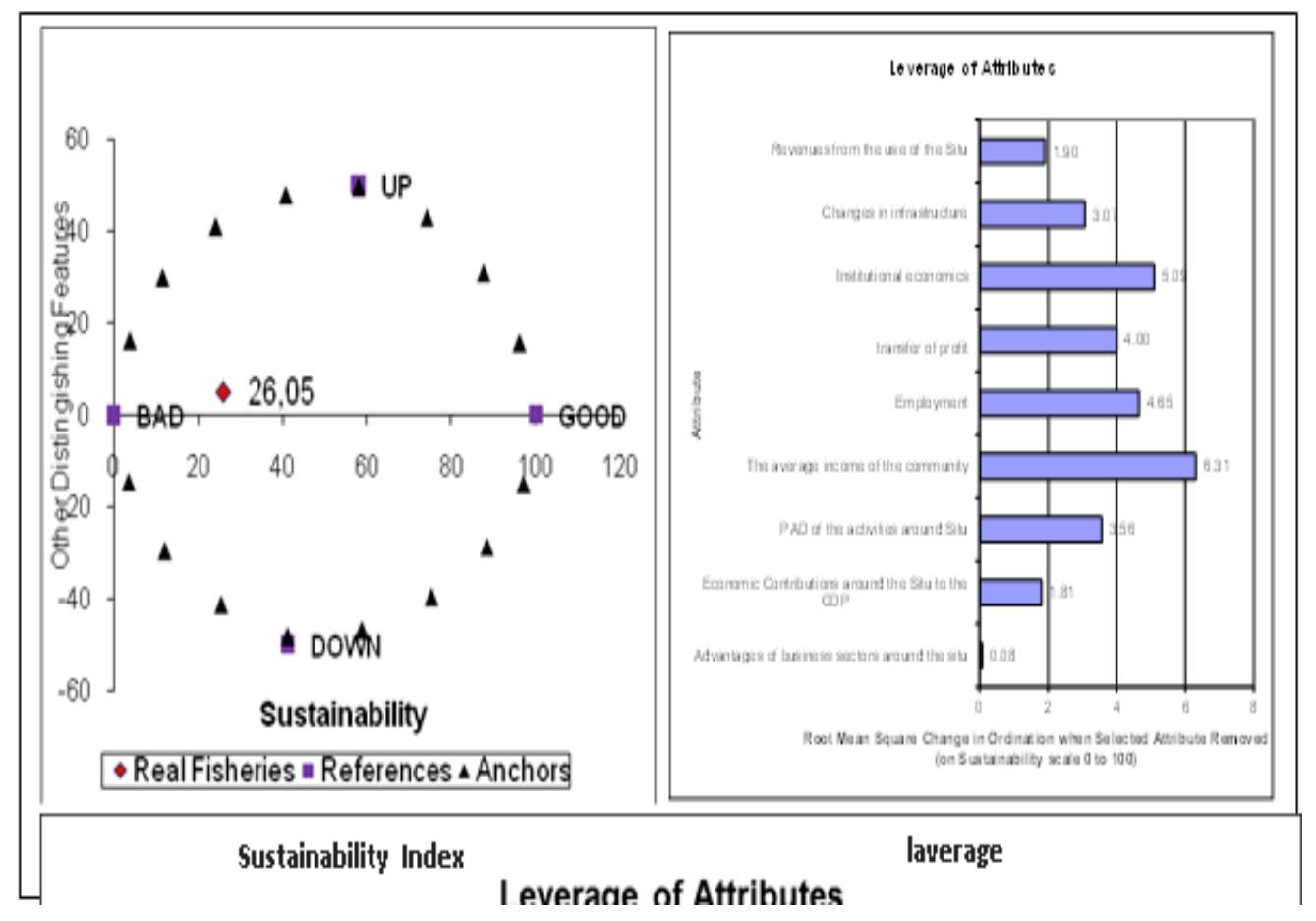

Figure 3. Value of Index sustainable and each atribut from economy dimentions 


\section{Social Dimension}

The results of the analysis of the index utilization sustainability Situ Kedaung from the social dimension shows an index of 40.28, including the category of less sustainable because the value of the index is in the range of 25-50. The results of the Laverage analysis of the social dimension showed that of the nine attributes were analyzed, there are three attributes that are sensitive to the use of the Situ, namely family participation, role of communities in the management Situ, and the frequency of conflict. Attributes role of family and community is very high influence in the management Situ, especially in the social dimension, because this attribute can change people's behavior in the sustainability of the Situ that is in terms of conservation, such as local wisdom prevailing in society, such as the fishing system.

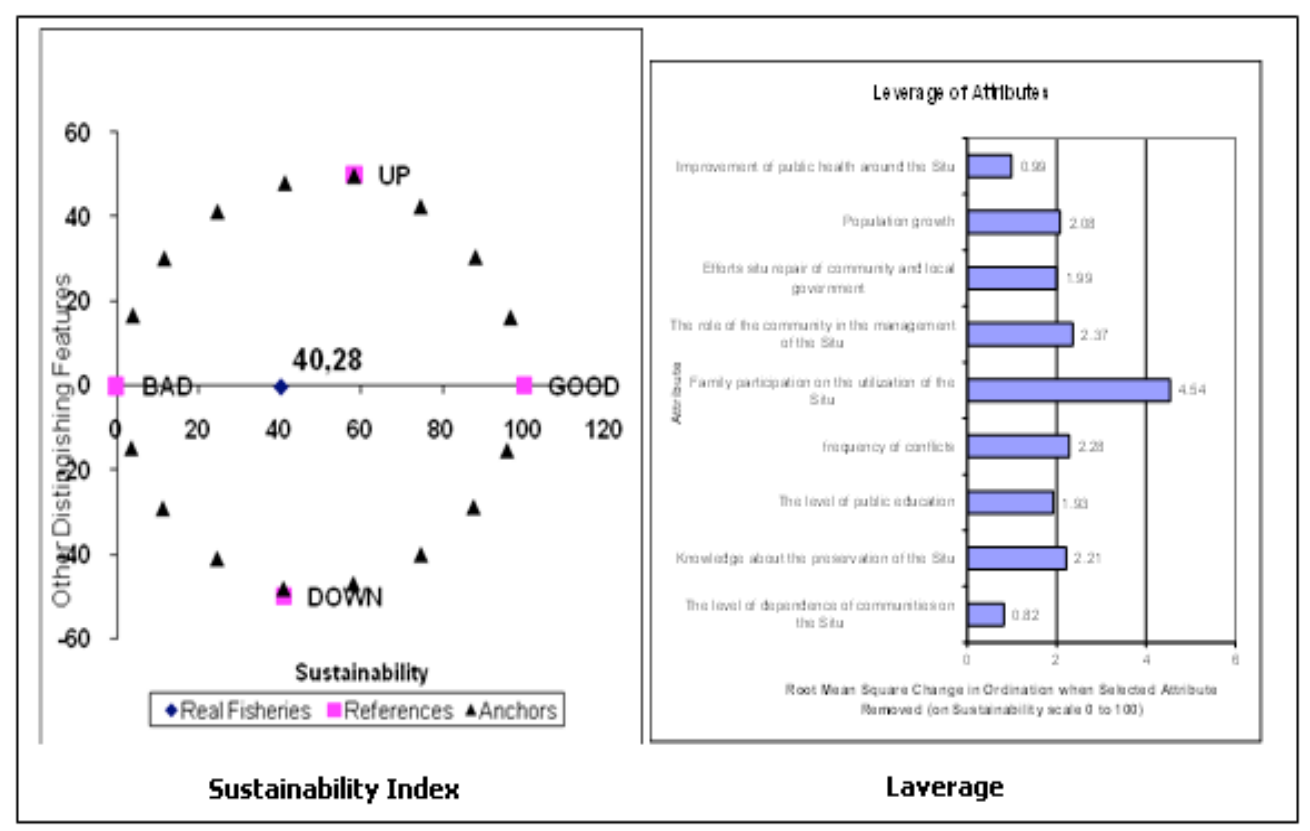

Figure 4. Value of Index sustainable and each atribut from social dimentions

\section{Technology Dimension}

The results of the analysis of the index utilization sustainability Situ Kedaung of technological dimension is 52.70 , it is in the category fair because the value of the index is in the range 50-75. The results of the analysis of the technology dimensions of sustainability laverage shows that of the four attributes were analyzed, there are two attributes that are sensitive in terms of information management and technology lake fishing. Both of these attributes are very big influence on the utilization of the 
lake, especially in the technological

dimension.

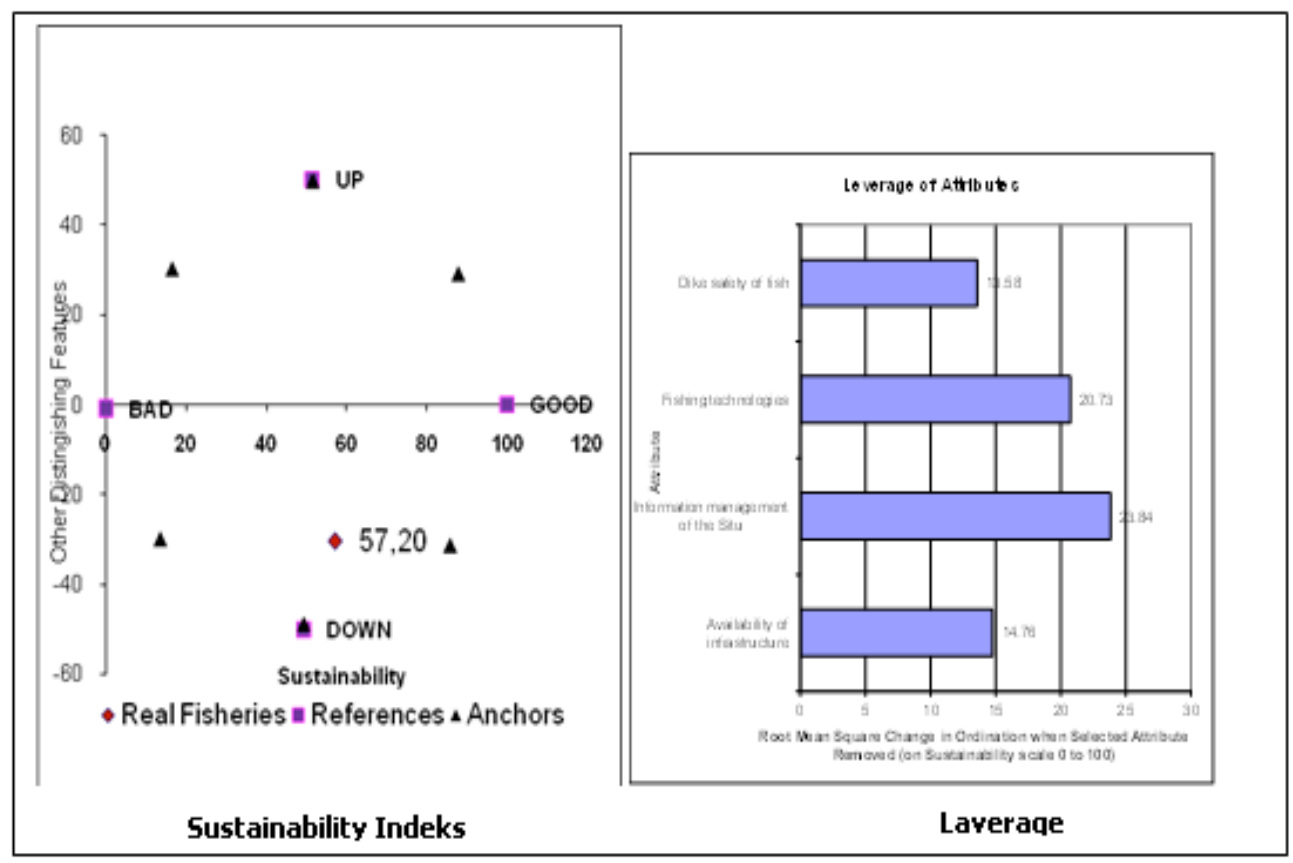

Figure 5. Value of Index sustainable and each atribut from technology dimentions

\section{Institutional Dimension}

The results of the analysis of the index utilization sustainability S utilization Situ Kedaung from institutional dimension is 26.91 including the bad category because the value of the index is in the range of 0 30. The results of the Laverage analysis show that, the six attributes are analyzed, there are three attributes that are sensitive, namely is Transparency in policy, legal lake management, and local watchdog. Attributes the existence of a local watchdog agency very high influence on the Situ management system especially on the institutional dimension, because this attribute is a forum for stakeholders to participate in conservation programs, other than that this institution serves as a facility for parties or establish cooperation with other institutions. If attribute the existence of local regulatory agencies have strengthened and well done it will change the system of utilization sustainable of Situ Kedaung. 


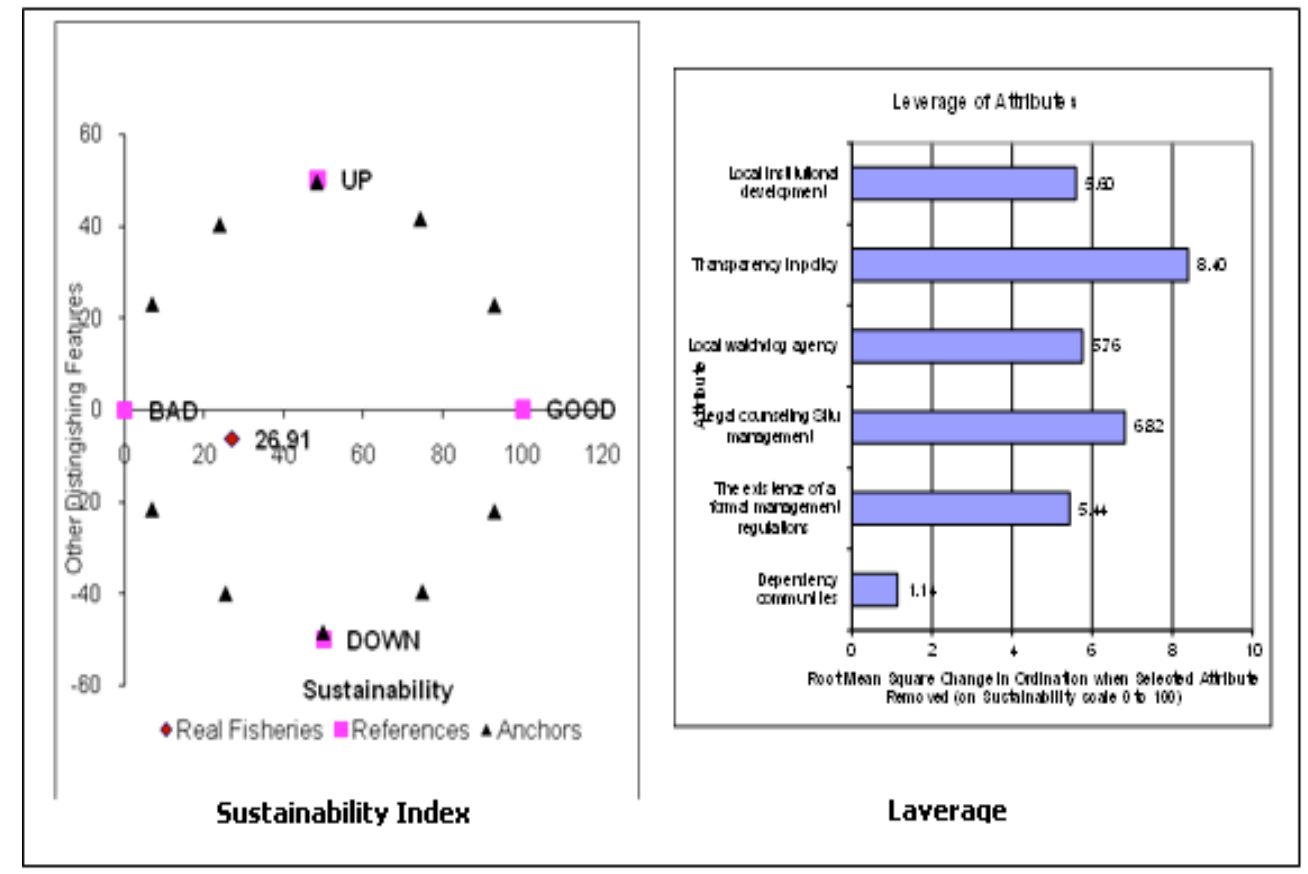

Figure 6. Value of Index sustainable and each atribut from institutional dimentions

To determine the index sustainability of management Situ Kedaung is used kite diagrams, of the five dimensions sustainability. and institutional) can be seen Figure 7 that the value is 36,65 is in the less category of

(ecological, economic, social, technological

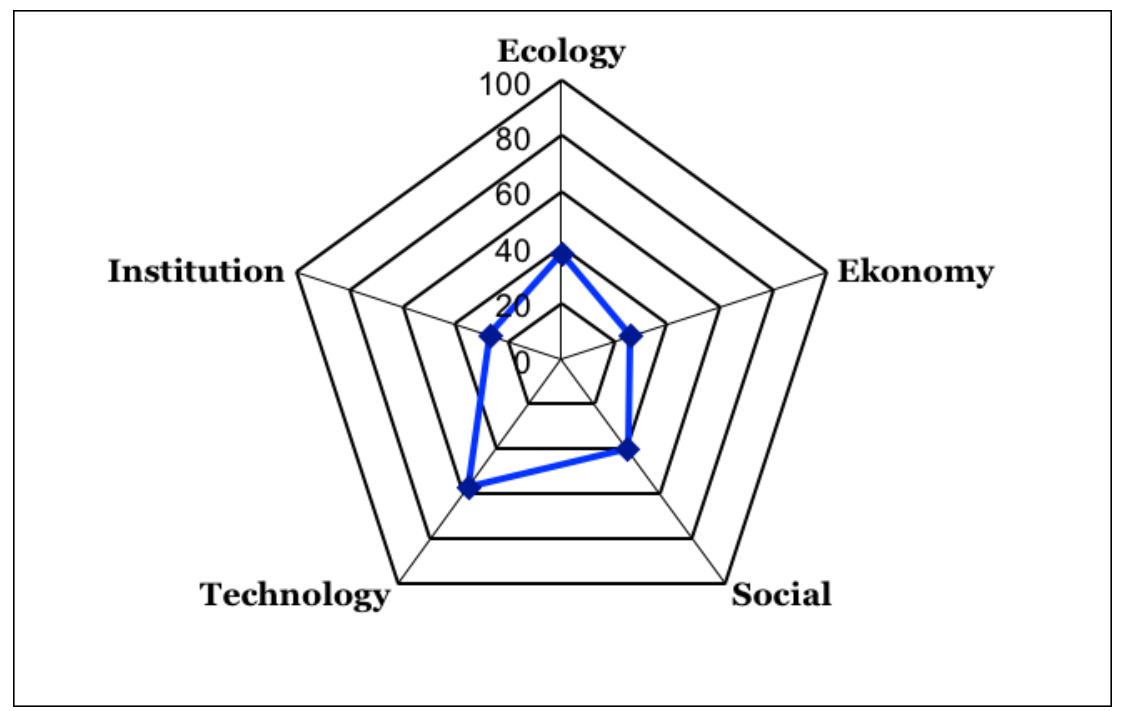

Figure 7. Sustainability Multidimension Value of Situ Kedaung 
The results of Monte Carlo analysis shows that the value of the $95 \%$ confidence level for each dimension and the combined five dimensions compared with the results of MDS have a relatively small difference. It shows the results of the calculation of MDS can reflect the actual value (Kavanagh and Pitcher, 2004). The results of Monte Carlo and MDS difference was also shown that the results of the analysis of the sustainability of the Situ Kedaung. MDS has a relatively small error in the determination of the scoring procedure attributes. It is caused by the lack of information, there is a relatively low error of the difference scores variations due to differences in opinion, MDS high level of stability, can be avoided errors in the entry or missing data and can be avoided high value of $\mathrm{S}$ tress. The results of Monte Carlo analysis for multidimensional sustainability index value and each dimension in detail can be seen in Table 1 .

Table 1.

The results of Monte Carlo analysis to value sustainability index mutidimensional and each dimension in the range of $95 \%$

\begin{tabular}{|l|r|l|l|}
\hline Index and Statust of Sustainability & DS & Monte Carlo & Diffecerences \\
\hline Multidimension & 36.65 & 38.12 & 1.47 \\
\hline Ecology & 37.32 & 38.51 & 1.19 \\
\hline Economy & 26.05 & 27.88 & 0.08 \\
\hline Technology & 52.70 & 55.95 & 3.35 \\
\hline Social & 40.28 & 40.36 & 0.08 \\
\hline Institutional & 26.91 & 27.90 & 0.99 \\
\hline
\end{tabular}

\section{Developing Scenarios or Strategies to}

\section{Manage Sustainability Situ Kedaung}

Situ Kedaung management strategies performed using prospective analysis which aims to predict the likelihood that will happen in the future in accordance with the objectives of improving the sustainable management of the Situ. Prospective analysis carried out through three stages, namely: (1) identify the key factors in the future, (2) determining the strategic objectives and interests of the main actors, and (3) define and describe the evolution of the possibilities in the future as well as determine a sustainable regional development strategy in accordance with resources.

Determination of the key factors in the analysis are taken from the key factors that affect the performance of the system is sensitive analytical results sustainability. Based on the analysis of leverage obtained 
14 factors (attributes) that are sensitive and subsequently submitted to the experts for assessment and further analyzed prospectively, which in turn is a key factor that affects the system performance analysis results sustainability Situ Kedaung.

Based on the results of the analysis of the level of interest among factors obtained five (5) key factors/determinants that have a strong influence and interdependence of factors is not too strong, namely: (a) water

\section{Preparing Scenarios}

Based on the prospective analysis there are five critical attributes that must be managed in order to guarantee the sustainability of the Situ Kedaung. Therefore it is necessary to formulate future scenarios Situ management strategies . Based on the analysis of the influence between factors, the key factors that influence and interdependence is further defined possibilities that will happen in the future. Based on the results of a prospective pollution, (b) ecotourism, (c) conservation, (d) income community and (e) local watchdog. Thus these five factors need to be managed well and made a variety of circumstances (state) that may occur in the future in order to realize a sustainable management Situ Kedaung. Key factors that are sensitive to be managed in the utilization of Situ Kedaung presented in Table 2, and figure 8

key factor Situ Kedaung management with a variety of circumstances for each factor, it is formulated various scenarios Situ Kedaung management strategies, namely: (1) Conservative - Pessimistic Scenario (survive on existing conditions while holding makeshift repairs); Moderate Optimistic Scenario (make improvements but not optimal) and (3) Progressive Optimistic Scenario (make improvements comprehensive and integrated

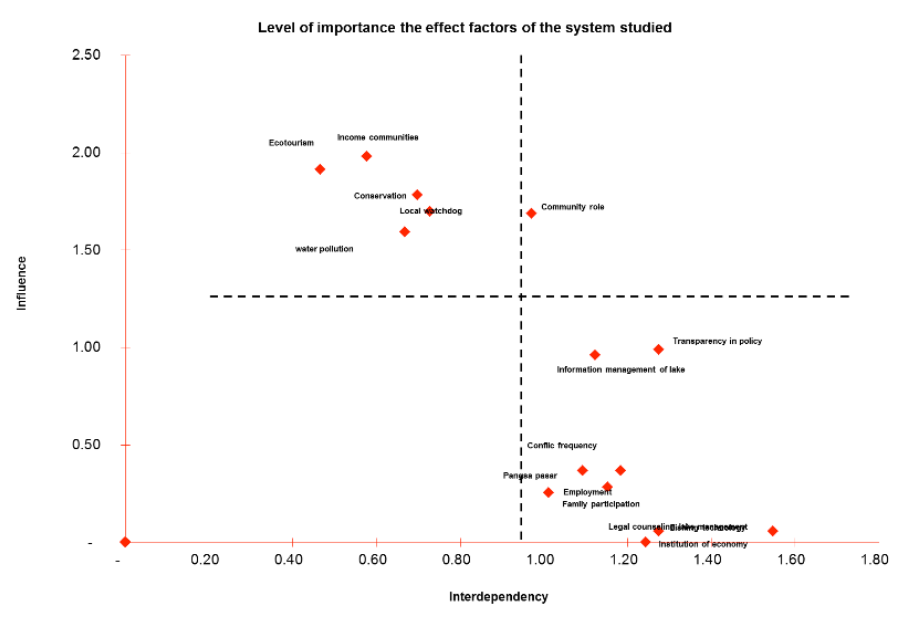


Figure 8. Sensitive attribute must be managed 
Tabel 2.

Sensitive Attributes that influence of Management Situ Kedaung

\section{No. Sustaninability Analysis Factor Ekology Dimension (3 Key Factors)}

1. Water Pollution.

2. Ecotourism

3. Consevation.

\section{Economy Dimension (3 Key Factors)}

4. Community income average compare to minimum regional salary (UMR)

5. Economic institution (partnership pattern)

6. Labor intensive

\section{Social Dimension (3 Key Factors)}

7. Community participaction for the utilization Situ

8. The role of community in management Situ

9. Conflict frequency

\section{Technology Dimension (2 Key Factors)}

10. Management information of Situ

11. Fishery technology

\section{Institution Dimention (3 Key Factors)}

12. Transparancy of policy

13. Law information on management Situ

14. Local watchdog.

Referring to the various possibilities that occur as mentioned above, it can be formulated that three groups management scenarios of Situ Kedaung in a sustainable manner most likely to occur in the future, namely :

1. Conservative - Pessimistic by modest improvements to the key attributes (factors).

2. Moderate - Optimistic by approximately 50\% improvement to key attributes (factors).

3. Progressive - Optimistic to make improvements to all key attributes (factors).

\section{CONCLUSIONS}

The ecological dimension of sustainability index of 37.32 , then the status is less sustainable. the economic dimension of sustainability index of 26.05, so the status is less sustainable. 52.70 with a fairly sustainable status, and institutional dimensions of sustainability index of 26.91 with less status of sustainability, so that overall status of the situ kedaung is less sustainable with index 36.65 . Based on the analysis of leverage obtained 14 factors 
(attributes) that are sensitive in the management of situ kedaung, namely: (a) the ecological dimension, the key factors are: water pollution, eco-tourism, and conservation, (b) the economic dimension, the key factors are: average community income to the minimum wage, institutional economics (a partnership), and employment,

(c) the social dimension, key factors include: family participation to the use of the situ, the role of the community in the management of the situ, and the frequency of conflict, (d) dimensions of technology, the key factors are: information management of the situ, and fishing technology, (e) institutional dimension, the key factors are: transparency in policy and law, management situ, as well as local regulatory agencies. The key factors/determinants that have a strong influence and interdependence of factors is not too strong include: water pollution, ecotourism, conservation, community income, watchdog agency is local. Scenario strategy management situ kedaung consists of : konservasif - pessimistic, namely the contamination of water is equal to the present time; ecotourism few visitors due to lack of promotion, conservation is often done; income levels are low, and social monitoring agencies do not exist, moderate - optimistic, namely the contamination of water is equal to the present time; ecotourism few visitors; conservation is rarely done; moderate income communities, and local regulatory agencies exist but are not effective, deal, by the way: water pollution below the threshold; ecotourism many visitors due to vigorous promotion; conservation is rarely done; highly-income communities, and local regulatory agencies exist and effective.

\section{REFERENCES}

Biro Pusat Statistik, 2014, Kecamatan Ciputat dalam Angka 2013, Biro Pusat Statistik Kota Tangerang Selatan

Biro Pusat Statistik, 2014, Kecamatan Pamulang dalam Angka 2013, Biro Pusat Statistik Kota Tangerang Selatan

Bond, Richard, Curran, Jahanna,Kirk Patrick, Lece, Norman, Francis, Paul, 2001, Integrated Impact Assessment for Sustainable Development, A Case Study Approach, University of Manchester, UK. Bourgeois R, and Jesus F. 2004. Partisipatory Prospective Analysis, Exploring and Anticipating Challenges with Stakeholders. Centre for Alleviation of Poverty through Secondary Corps Development in Asia and the Pasific and French Agricultural Research Centre for International Development, Monograph.

Bourgeois R. 2007. Bahan pelatihan Analisis Prospektif Partisipatif. Training of Trainer ICASEPS. Bogor 
Dinas Bina Marga dan Sumberdaya Air

Tangerang Selatan, 2010, Laporan

Tahunan Dinas Bina Marga dan

Sumberdaya Air Kota Tangerang Selatan,

Propinsi Banten.

Godet, M. 1999. Scenarios and Strategies. A

Book for Scenario Planing Librairie des

Arts et Methods. Paris . France.

Hardjomidjojo, H. 2006. Panduan Lokakarya

Analisis Prospektif. Materi Kuliah PS -

Marten, Gerald G, 2001, Human Ecology,

Basic Concept for Sustainable

Development, London.

Mitchel B, 1997, Resource and Enveronment

Management, University of Waterlo,

Waterlo Ontario.

Roderic, G, Meppem, Tony, 1997, Planning

for Sustainability as a Learning Concept,

New Englend Ecological Economic Group.

Centre for Water Policy Research,

University of New England, Armidale,

Australia.

Salim E, 2004, Membangun Indonesia

2005- 2020, Jurnal Ekonomi

Lingkungan, Edisi 13 Tahun 2004.

Suryadiputra, I.N.N, 1998, Penelitian Danau-

danau di Jabotabek, Workshop

Pengelolaan Danau-danau di wilayah

Jabotabek.

Undang-undang No. 26 tahun 2007, tentang Penataan Ruang.

Undang-undang No. 32 tahun 2009, tentang

Perlindungan dan Pengelolaan
PSL, Sekolah Pasca Sarjana. IPB. Bogor.

Indrasti R, 2002, Upaya Pengelolaan Danau

Babakan Sebagai Kawasan Wisata Agro

Berkelanjutan di DKI Jakarta, Thesis,

Program Pascasarjana IPB, hal 114.

Kavanagh, P, 2001, Rapid Appraisal of

Fisheries (Rapfish) Project, Rapfish

Software Description (for Microsoft Exel),

University of Britsh Colombi

\section{Lingkungan Hidup}

World Commision on

Environment and Development, 1987, Our

Command Future, PT.Gramnedia, Jakarta. 
